\title{
ТЕКСТОВИЙ КОНТЕНТ САЙТУ ЯК ЖАНР РЕКЛАМИ
}

ㄷ П. О. Киричок, д.т.н., професор, А. О. Дем'янова, НТУУ «КПІ», Київ, Україна

Исследованы особенности веб-текстов рекламного назначения. Обобщены требования к рекламным текстам в сети на основе трех параметров: веб-среда, реклама и «раскручивание" сайта. Рассмотрены сайты за их отношением к рекламе - самостоятельные ресурсы и сугубо рекламные сайты. Проанализировано состояние отечественного рекламного контента на примере сайтов украинского сегмента Интернета.

Features of web texts of advertising appointment are investigated. Requirements to advertising texts in a network on the basis of three parametres are generalised: web environment, advertising a site. Sites behind their relation to advertising - independent resources and especially advertising sites are considered. The condition of a domestic advertising content on an example of sites of the Ukrainian segment of the Internet is analysed.

3 початком нового тисячоліття ставлення користувачів до інтернет-реклами значно змінилося. Зниження ефективності банерної реклами, якісна фільтрація електронних розсилань змусили рекламодавців шукати нові методи привернення уваги користувачів та стимулювання продажів. Інтернет став сприйматися як новий тип ЗМl, а реклама для цього каналу почала розроблятися за традиційними маркетинговими принципами, щоправда, з урахуванням специфіки мережі [1]. Дешеву і часто саморобну рекламу 90-х поступово витісняють міжресурсні партнерські програми, банерний таргетинг та цільове позиціювання (контекстна реклама) за допомогою пошукових систем нового покоління (Goog- le, Yahoo, Yandex тощо). Також значну увагу маркетологи почали приділяти текстовій рекламі - створенню якісних сайтів 3 інформативним контентом, що не лише привертає та утримує увагу випадкових користувачів Інтернету, а й ефективно стимулює продажі, отже стало пріоритетним завданням для компаній-виробників товарів та послуг [2]. Основним чинником рекламної комунікації в мережі $\epsilon$ контент сайту, його «душа», тобто інформаційне наповнення ресурсу (зображення, текст, мультимедійні файли). Звичайно, саме текстове наповнення відіграє найважливішу роль, оскільки від якісного текстового контенту на $80 \%$ залежить успіх сайту.

Текстовий рекламний контент - новий жанр Інтернет- 


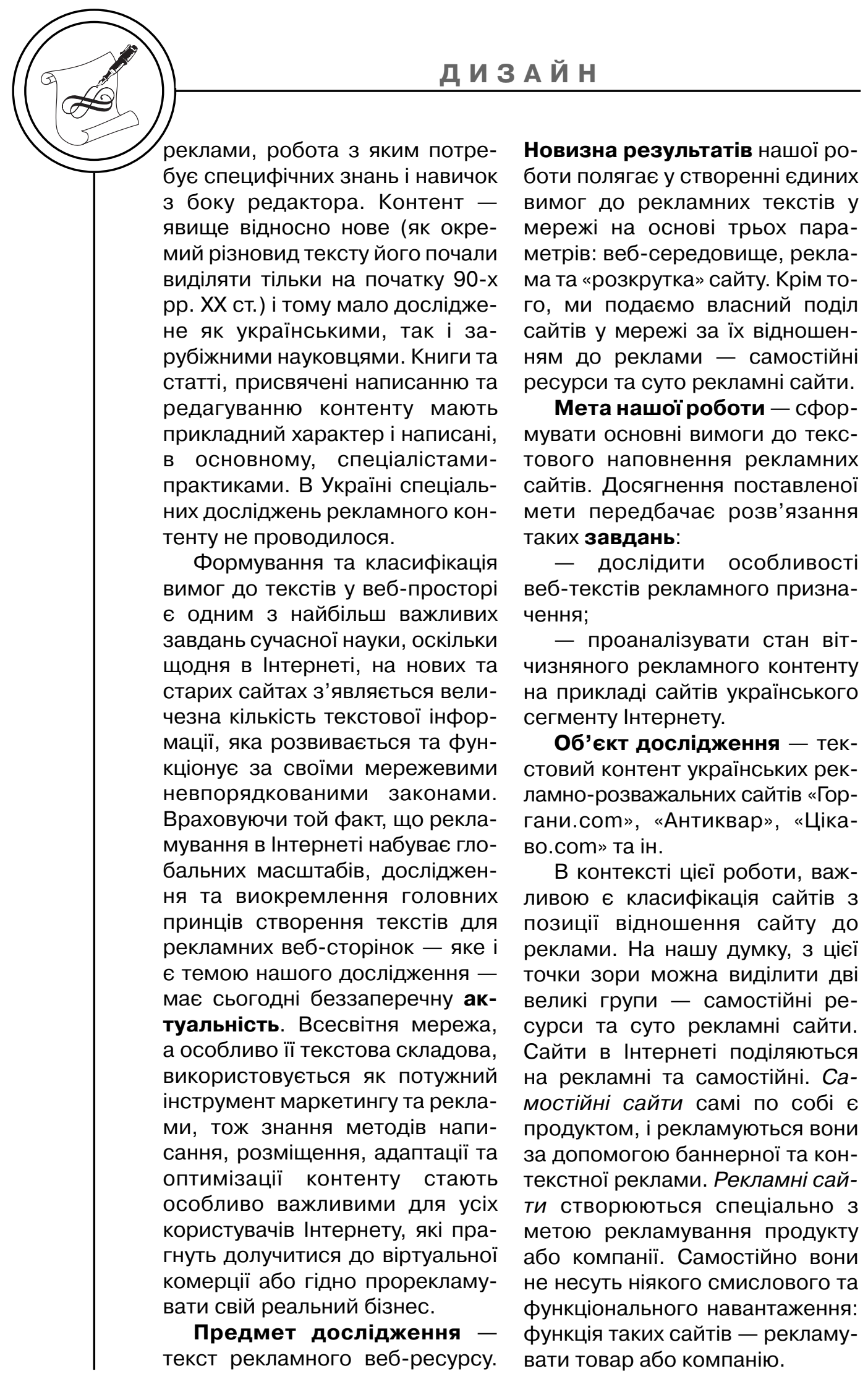


Створення рекламного сайту в Інтернеті сьогодні $€$ обов'язковою ланкою маркетингової діяльності будь-якої сучасної організації - від маленької приватної фірми до великого міжнародного концерну. Такі сайти $€$ не тільки ефективним способом створення іміджевої реклами, вони надають доступ клієнтам до корпоративної інформації у будь-якій точці планети та в будь-який час. Залежно від типу контенту та призначення сайту, на якому його буде розміщено, структура web-текстів може суттєво відрізнятися в плані оформлення заголовків, поділу тексту на абзаци та використання гіперпосилань.

На нашу думку, з точки зору рекламних функцій та структурних особливостей доцільно виділити три види рекламних сайтів у мережі.

Сайт-візитка. Це невеликий сайт, який містить інформацію про компанію, її діяльність, продукцію, контакти тощо. Такий сайт найбільше підходить для невеликих компаній вузької направленості. Наприклад, сайтвізитка компанії «Слобожанський миловар», яка є виробником відомої марки мила «Шик», www.soap.com.ua - складається з кількох невеликих розділів (Продукція, Новини, Контакти тощо), й оформлений із використанням флеш-анімації. Сайт надає відвідувачу необхідну рекламну інформацію, і виконує презентаційну функцію.

Корпоративний сайт. Великий сайт (або навіть портал) компанії, який містить детальну інформацію про компанію, про іï послуги чи продукцію, про співробітників. На корпоративному сайті може бути вміщений детальний каталог продукції компанії, діяти Інтернет-магазин та інші сервіси. Наприклад, сайт компанії «Бритіш Американ Тобакко Україна» - www.bat.ua вміщує такі розділи як Про компанію, Наша діяльність, Соціальна відповідальність, Соціальний звіт 2006-2007, Куріння і здоров'я, Регулювання, Прес-центр, Кар'єра. Кожен із цих розділів має ще декілька підрозділів (які теж іноді поділяються на менші категорії). Крім того, на сайті можна скачати різноманітні файли про діяльність компанії, прайси, публікації, скористатися різними сервісами.

Презентаційні сайти. Створюються для реклами певного товару або марки, більше за всі інші виконують саме рекламну функцію. Такі сайти зазвичай невеликі, проте яскраві - у них застосовуються флеш-технології, звук, відео, інтерактивні елементи. Приклад - сайт www.pioneer-kuro.com.ua, присвячений плазменному телевізорові Kuro. Концепція, структура та наповнення сайту постійно змінюється, в залежності від того, яка саме рекламна компанія проходить у цей час. Коли відвідувач завантажує першу сторінку, він спершу бачить рекламний флешролик, а потім потрапляє власне на сайт із багатьма графічними елементами та інтерактивними формами.

3 огляду на те, що будь-який сайт в мережі потребує реклами, кожен рекламний сайт є одночасно і сайтом рекламованим 


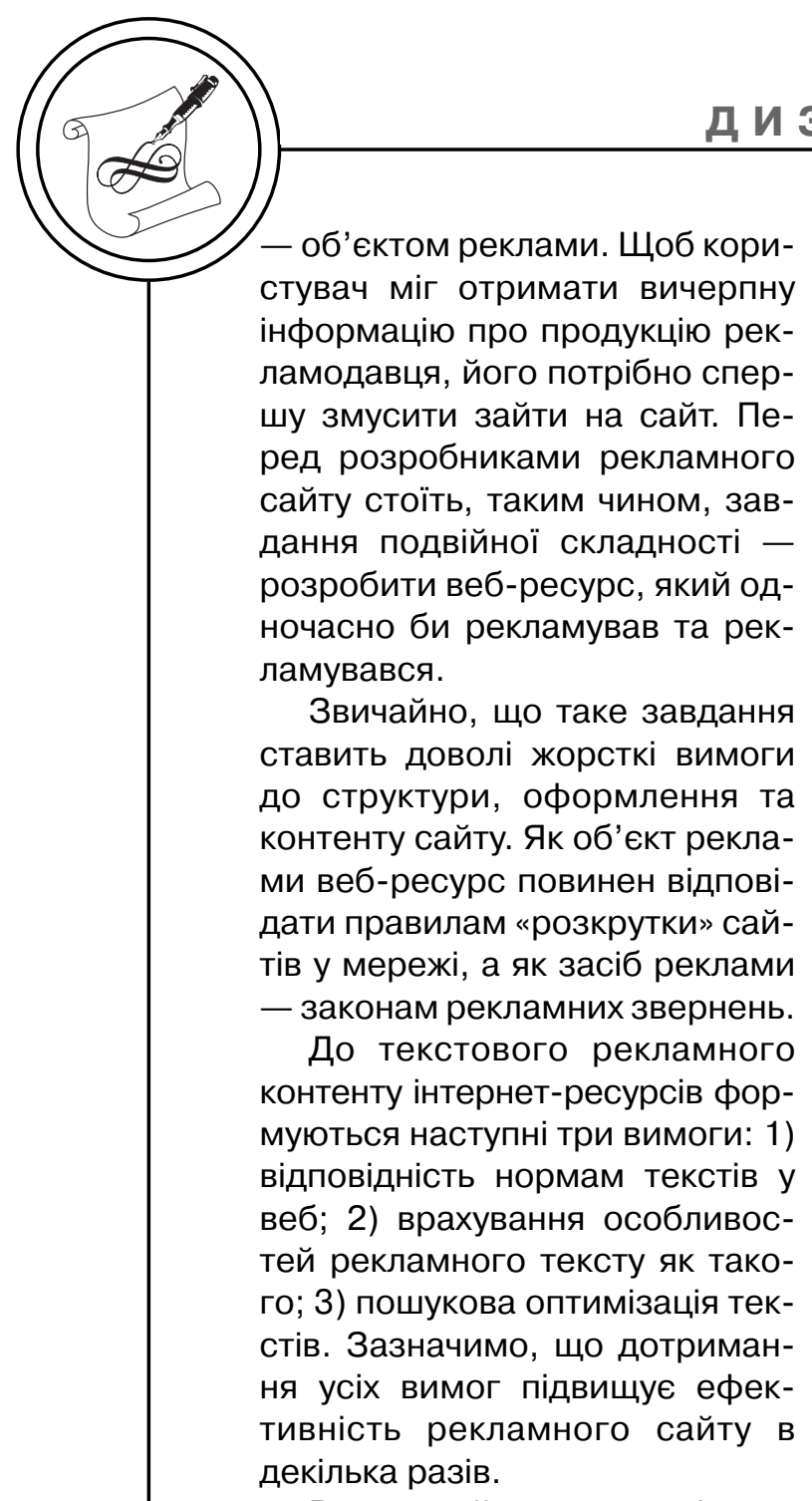

Рекламний контент в інтернет-середовищі виконує чотири основних функції - інформативну, іміджеву, комерційну та атракційну. Інформаційний контент знайомить читачів із пропонованими товарами та послугами, діяльністю компанії та пов'язаними із нею подіями. Іміджевий покликаний викликати у читача стійкі позитивні асоціації з брендом, торговою маркою, назвою компанії тощо. Комерційний рекламний контент призначений для миттєвої або перспективної стимуляції продажів конкретних товарів чи послуг.
Атрактивний контент використовують для приваблення користувачів мережі до окремого ресурсу, сервісу, серверу - так рекламують новинні, поштові, розважальні ресурси, сервери знайомств тощо [3, С. 116].

Узагальнимо кілька правил написання рекламного контенту:

- писати коротко;

- писати так, щоб текст було зручно переглядати;

- писати точно за темою, а не заповнювати простір рекламним шумом.

Текст для сайту повинен:

1) відповідати на запити користувачів;

2) використовувати для цього просту мову без спеціальних термінів (це також покращує релевантність тексту для пошукових систем, бо користувачі здебільшого шукають потрібні документи не за специфічними термінами) [4].

Успішність та ефективність рекламного контенту визначається позицією сайту в рейтингу пошукових систем за популярними запитами. Для збільшення рейтингу власники сайтів вдаються до комплексу заходів з оптимізації сайту (SEO), серед яких дуже важливою $є$ оптимізація текстової складової сайту. Рекламний текст має повністю відповідати запитам користувачів і використовувати для цього просту мову без спеціальних термінів. Адаптація текстів до вимог пошукових систем дозволяє підвищити рейтинг сайту серед користувачів Інтернету.

Рекламний контент українського сегменту Інтернету поки не відрізняєтся високою якістю очевидно, що на більшості сай- 
тів його створенням займаються люди, не пов'язані ні з копірайтингом, ні 3 редагуванням. щоб адекватно оцінити помилки в написанні рекламного контенту, проаналізуємо кілька текстів комерційних та розважальних сайтів.

Приклад 1. Текст з рубрики «Про нас» інтернет-магазину спортивного спорядження.

«Мандруй сміливо з Gorgany.com.

З 2005 року інтернет-магазин Gorgany.com доставляє найякісніше спорядження в усі куточки України. Туризм, альпінізм, лижі, одяг та взуття для подорожей та пригод. Наш асортимент постійно розширюється i ми намагаємось донести до Вас все найцікавіше, що пропонують світові виробники туристичного спорядження. Ми постачаємо тільки те, що є надійним, і на що ми можемо дати гарантію.

Купівля в інтернеті - це зручно та надійно. Ми відкриті 24 години на добу, 7 днів на тиждень. Підберемо, порадимо, доставимо. Наша мета, щоб Ваша покупка принесла Вам якнайбільше задоволення.

Gorgany.com має головний офіс у Львові і представництво у Києві.

З 2007 року у Львові працюе магазин "Gorgany.com Туристичне Спорядження». Якщо купівля через інтернет для Вас щось нове та незнайоме дзвоніть або заходьте. Будемо раді зустрітися.

Щиро Ваші, Gorgany.com

Як нас знайти?

Новини та події Gorgany. com...»[5].
Перше, що впадає у вічі неінформативний заголовок та відсутність внутрішньосайтових гіперпосилань, які були б цілком вмотивовані в такому тексті. Детальний аналіз показав, що три останніх фрази тексту $є$ посиланнями, проте вони належно (кольором та підкресленням) не відмічені, тож пересічний користувач їх не помітить і не скористається ними. Також у тексті порушена логіка викладу - автори починають з історії інтернет-магазину, потім у загальних фразах викладають основну думку матеріалу - чим саме займається магазин. Після цього невмотивована і неправдива інформація про переваги купівлі в Інтернеті (в тексті подана інформація «Ми відкриті 24 години на добу, 7 днів на тиждень», проте доставка товарів здійснюється тільки в робочі дні з 9 до 20 години). Далі розміщено дуже неповну контактну інформацію, яка теж $€$ надзвичайно важливою для рекламних текстів, оскільки дозволяє потенційному покупцю напряму зв'язатися 3 організацією та перевірити хоча б частково надійність сервісу або висунути за потреби претензії. В тексті зустрічаються помилкові конструкції («Наша мета, щоб Ваша покупка принесла Вам якнайбільше задоволення» або «Будемо раді зустрітися»).

Приклад 2. Текст розміщено на інформаційно-розважальному сайті в якості поточної новини.

\section{«Limonex: Акція для Інтер- нет Магазинів}

Система Інтернет-платежів Limonex пропонує нові можли-

x

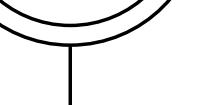




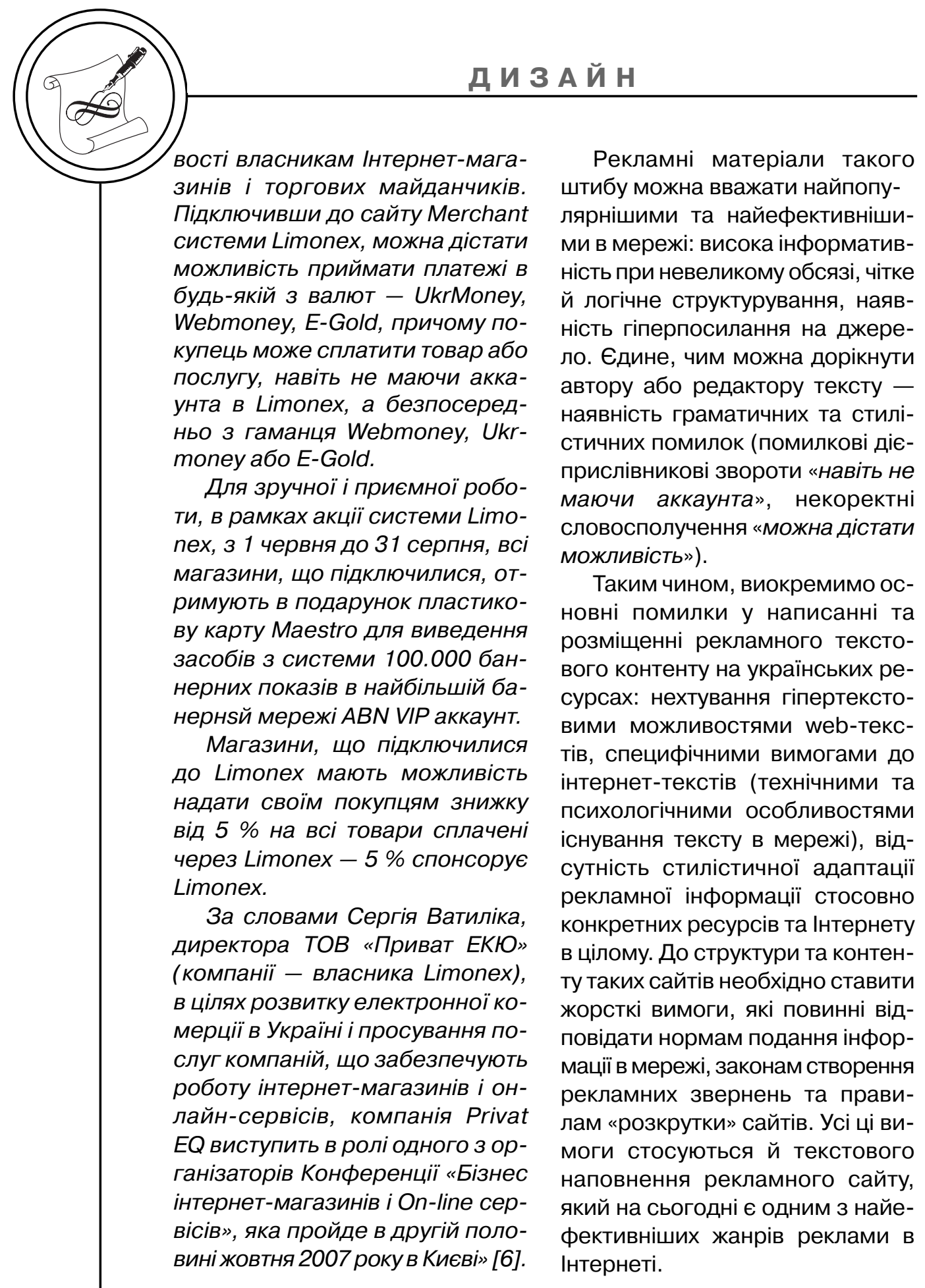

1. Мельник В. Текстовый контент: основные правила веб-копирайтинга / В. Мельник // http://azurel10n.com.ua/ar_wrules.htm. - 2008. - 10 жовт. [дата відвідув.]. 2. Иванова К. А. Копирайтинг: секреты составления рекламных и PR-текстов / К. А. Иванова. - СПб. : Питер, 2008. - 160 с. - ISBN 978-5-469-02208-8. 3. Васильев Г. А. Электронный бизнес: реклама в Ин- 
тернете / Г. А. Васильев, Д. А. Забегалин. - М. : ЮНИТИ-ДАНА, 2007. - 183 c. - ISBN 978-5-238-01346-6. 4. Henning K. The seven qualities of highly successful web writing / K. Henning // http://www.clickz.com/833861. - 2000. 12 груд. [дата розміщ.]. 5. Мандруй сміливо 3 Gorgany.com // http://www.gorgany.com/about_us.php. - 2008. - 14 листоп. [дата відвідув.]. 6. Акція для Інтернет-магазинів // http://cikavo.com/article/3913.html. - 2008. - 26 лип. [дата розміщ.].

Надійшла до редакції 22.12.08 